\title{
How to achieve students' self-management in educational activity?
}

\author{
Liudmyla Bilousova ${ }^{1}$, Larysa Kolgatina ${ }^{1}$, and Oleksandr Kolgatin ${ }^{2, *}$ \\ ${ }^{1}$ H. S. Skovoroda Kharkiv National Pedagogical University, 29 Alchevskykh Str., Kharkiv, 61002, Ukraine \\ ${ }^{2}$ Simon Kuznets Kharkiv National University of Economics, 9a Science Ave., Kharkiv, 61166, Ukraine
}

\begin{abstract}
The paper is devoted to the study of types of managing the student's educational activity. The educational discipline "Practicum of problem solving in informatics" for students of third year study, future teachers of informatics have been chosen for realising pedagogical conditions of computer-oriented management of students' educational activity. Progressive turn from direct management through comanagement, subsidiary management to self-management was the main idea of designing the courseware. The information and communication educational environment has been based on the platform of learning management system Moodle. The Workshop elements of Moodle played the central role in management of students' educational activity. The results of our pedagogical observation and assessment showed the efficiency of suggested approach. Additionally, there were shown the lack of students' competency in time planning and introspection on the base of the experimental data.
\end{abstract}

\section{Introduction}

\subsection{Statement of the problem}

Informatisation of the educational process has led to the creation of information and communication educational environment in institutions of higher education and significantly influenced the goals, content, methods and means of students' educational activity, forms of its organization. The use of modern powerful computer tools for management tasks implementation in educational process means the transition to a new type of management - computer-oriented, which can provide the personalisation and not only serve the achievement of learning goals, but also help the student to become the active participant of such management, that is the subject of self-management. This task of introducing in education of innovative management practices, oriented on the use of information and communication technologies, remains relevant today.

\subsection{Analysis of previous research}

One of the most fundamental analysis of theoretical and methodological aspect according to the management of the independent learning activity of students of pedagogical higher educational institutions was suggested by O. V. Malykhin [1]. Recently, appropriate methodical systems have been introduced into the practice of the educational process to provide for computer-based management of students' educational activity. Information and communication educational technologies, especially, cloud technologies that transform education have been analysed according to results of the "Cloud Technology in Education" scientific conference by A. E. Kiv, V. N. Soloviev, S. O. Semerikov [2]. O. O. Lavrentieva, L. M. Rybalko, O. O. Tsys, and A. D. Uchitel [3] have analysed new methods of the organization of students' independent study activities together with the use of ICT and tools. Computer-based tools of supporting students' independent experimental activity in the process of learning quantum physics have been proposed in the work of S. P. Velychko and S. V. Shulga [4]. Management of students' educational activity was provided as support in instrument setup, measurements, results processing. K. V. Vlasenko, I. V. Sitak, O. O. Chumak [5] have designed and are developing an educational site "Differential Equations" to support students' educational activity. The site contains theoretical framework, practical classes, provides consultations on-line and via e-mail, testing, discussion cases, forum and provides support for the teaching of the course and solving practical problems of research character by students. S. O. Podlasov, O. V. Matviichuk, V. P. Bryhinets [6] have proposed elements of blended training in physics at a technical university on the basis of programmed learning (students study new material or fixate their knowledge) in the Moodle system with the help of the element Lesson. M. A. Kyslova and K. I. Slovak [7] developed methods of using the mobile learning environment in study of higher mathematics by future electromechanical engineers. These methods are based on the complex application of computer tools: using Google Apps Education Edition (texts, diagrams, links, videos); execution of practical tasks and research with developed models in cloud-oriented GeoGebra and CoCalc environments; application of Drawings for

\footnotetext{
* Corresponding author: kolgatin@ukr.net
} 
generalization and systematization of concept connections, Forms for testing, CoCalc for task generation. Tools integration was provided with using Classroom, Calendar was used for scheduling training activities. O. O. Triakina, O. O. Pavlenko, N. P. Volkova, D. A. Kassim [8] analysed E-learning instruments for self-education and have suggested the ways of this tools implementation into professional training. Methods and technologies for the quality monitoring of electronic educational resources were analysed by $\mathrm{H}$. M. Kravtsov [9]. A methodical system of computer-oriented management of independent work of future teachers in the process of learning computational methods (numerical methods) was developed in the works of L. I. Bilousova, O. G. Kolgatin, L. S. Kolgatina [10]. This system is based on the use of specially designed computational models in MathCAD environment and assumes learning management system Moodle to support for management of students' independent work. It should be noted that development of the educational process on the basis of its reorientation to students' self-management their own cognitive activity not only contributes to enhancing the autonomy of students, but also gives the education of personal significance. By determining the individual trajectory of educational and cognitive activity of each student on the basis of the maximum consideration of his individual and cognitive abilities, the necessary prerequisites for the formation of his skills of systematic and continuous professional self-improvement are created. Useful analysis in this direction were suggested by B. I. Kruk, O. B. Zhuravleva [11].

\subsection{Objectives}

The potential of computer-oriented management of students' educational activity is not fully realized, according to the above analysis. It actualizes the study of pedagogical conditions, the introduction of which improves the effectiveness of such management by contributing to the future teachers in obtaining better educational results and in acquisition of the active personal position in managing their own independent work.

The aim of this paper is in theoretical and practical study of pedagogical conditions of effective computeroriented management of students' educational activity and progress from direct management through comanagement and subsidiary management to selfmanagement in information and communication educational environments.

\section{Theoretical framework}

There are various approaches to defining the concept of management in pedagogical systems in the psychopedagogical literature. Thus, M. Markov [12] views management as an organization of purposeful actions, I. B. Itelson [13] sees management as the actions that are directed to achieving a previously set goal. $\mathrm{Yu}$. M. Korshunov [14] considers that management is the organization of a process that ensures the achievement of a predetermined goal. A. V. Filippov [15] considers management as the purposeful influence of the subject on the object and the change of this object as a result of influence. V. Nechaev [16] speaks about management as purposeful regulation of processes. In some studies, management is seen as an element of some system that connects all its elements and subordinates them to the goal. Thus, V. Yakunin [17] sees the essence of management in the interaction of the student and the teacher, which is carried out in accordance with the set goals and is aimed at activating the student's activity in the learning process and achieving the required results. We agree with all of the above statements, which highlight certain features of management and confirm the relationship between management and activities. It is also defined by the interpretative dictionary: "To manage 1. To direct activity, work of someone, something; be led by someone, something; manage. 2 . To direct the course of a process, to influence the development, the state of something" [18]. On the basis of this analysis of pedagogical research on the problem, the essence of managing student's educational activity is determined as realization of interaction of a student and a teacher, which is aimed at activating student's activity in the educational process and achieving the educational goals. As a result of this interaction, the social and cognitive experience of the student changes, which acquires the trait of independent, purposeful activity in order to become ready to solve future professional problems.

The development of information and communication technologies creates prerequisites for improving the efficiency of managing students' educational activity in modern higher education process. Given the new role of the teacher as a tutor, a moderator, who provides support to the student in choosing and building an individual educational trajectory, the new quality of management is seen in its variability, coordination of management actions with individual capabilities, needs and requests of the student. This management is directed to help the student to get knowledge and skills according to the curricula, but also to increasing involvement of the student in managing their own educational activity, in the progressive transition from direct management to comanagement, subsidiary management and further to selfmanagement. ICT-oriented management of student's educational activity is a multi-stage process (collection of information, statement of objectives, decision-making, implementation of the decision, monitoring and evaluation of results, adjustments) that is implemented with the use of appropriate ICT tools at each stage. Implementing student's self-management with the use of modern, powerful computer management tools means moving to a new type of management - computeroriented, capable to provide higher quality of management. The new quality of computer-oriented management of student's educational activity is due to the following features:

- adaptability that is based on detailed data on the level of knowledge and skills of the future teacher required for independent work, as well as on the dynamics of their acquisition;

- flexibility that assumes gradual involving of a student in improving management of his / her own independent work through the transition from direct management to co-management, subsidiary management and self- 
management on the base of analysis of the accumulated experience of using a certain type of self-management and data on its effectiveness;

- timeliness, which is provided by the opportunity to monitor the process of the task execution and the availability of communication resources, that allows timely and targeted assistance and advice to the student, based on the accumulation and analysis of data on the progress and effectiveness of his educational activity;

- transparency, which involves openness of requirements to the results of the educational activity, criteria for the evaluation, rating indicators of educational achievements of the future teachers;

- objectivity in making managerial decisions that is based on objective testing data and tracking the effectiveness of the student's educational activity.

On the basis of the analysis of new opportunities for managing the student's educational activity, pedagogical conditions for the effective implementation of the said management in the educational process have been substantiated:

- designing of information and communication educational environment, which contains variation educational-informative,

instructive-methodical, software-instrumental, as well as communication resources for organization and support of the student's educational activity;

- using a system that automates the collection, accumulation and analytical processing of performance indicators of student's educational activity;

- ensuring the readiness of all participants in the educational process to implement computer-oriented management of the student's educational activity.

Only comprehensive application of all conditions ensures the effective management. The implementation stage of ICT-oriented student's educational activity management is the key stage, when the student actively takes part in this management as the person of educational process. Understanding the character of interconnections between the teacher and the student (Table 1) is very important to developing the flexible management based on different types of management (direct management, co-management, subsidiary management, and self-management).

Table 1. Activities of the subjects of the educational process at different management types on the stage of implementation of the decision.

\begin{tabular}{|c|c|c|c|}
\hline \multicolumn{4}{|c|}{ Type of management } \\
\hline Direct management & Co-management & Subsidiary management & Self-management \\
\hline $\begin{array}{c}\text { The teacher sets a task for the } \\
\text { student }\end{array}$ & $\begin{array}{c}\text { The teacher discusses a task } \\
\text { with the student }\end{array}$ & $\begin{array}{c}\text { The student chooses a task from a } \\
\text { database }\end{array}$ & $\begin{array}{l}\text { The students formulates a task } \\
\text { and coordinates it with the } \\
\text { teacher }\end{array}$ \\
\hline $\begin{array}{l}\text { The teacher sets the methods } \\
\text { of the task execution }\end{array}$ & $\begin{array}{l}\text { The teacher discusses the } \\
\text { methods of the task } \\
\text { execution with the student }\end{array}$ & $\begin{array}{l}\text { The student chooses the methods of } \\
\text { the task execution from suggested by } \\
\text { the teacher }\end{array}$ & $\begin{array}{l}\text { The student determines the } \\
\text { methods of the task execution } \\
\text { independently }\end{array}$ \\
\hline $\begin{array}{c}\text { The teacher suggests } \\
\text { necessary resources to for the } \\
\text { student }\end{array}$ & $\begin{array}{l}\text { The teacher suggests } \\
\text { necessary resources to for } \\
\text { the student }\end{array}$ & $\begin{array}{l}\text { The student chooses necessary } \\
\text { resources from the given resource base }\end{array}$ & $\begin{array}{l}\text { The student determines the } \\
\text { necessary resources } \\
\text { independently }\end{array}$ \\
\hline $\begin{array}{c}\text { The teacher gives the } \\
\text { example of the correct } \\
\text { operation sequence (detailed } \\
\text { instruction) }\end{array}$ & $\begin{array}{l}\text { The teacher gives the } \\
\text { common schema of the } \\
\text { operation sequence } \\
\text { (framework instruction) }\end{array}$ & $\begin{array}{l}\text { The student determines the operation } \\
\text { sequence independently }\end{array}$ & $\begin{array}{l}\text { The student determines the } \\
\text { operation sequence } \\
\text { independently }\end{array}$ \\
\hline $\begin{array}{c}\text { The teacher provides current } \\
\text { correction of the task } \\
\text { execution process }\end{array}$ & $\begin{array}{l}\text { The teacher adjusts the } \\
\text { process of completing the } \\
\text { task, if necessary }\end{array}$ & $\begin{array}{c}\text { The teacher adjusts the process of } \\
\text { completing the task, if the student ask } \\
\text { him for help }\end{array}$ & $\begin{array}{l}\text { The student controls the task } \\
\text { completing process } \\
\text { independently }\end{array}$ \\
\hline $\begin{array}{l}\text { The teacher provides the } \\
\text { student with current } \\
\text { systematic help }\end{array}$ & $\begin{array}{l}\text { The teacher helps the } \\
\text { student, if necessary }\end{array}$ & The teacher helps, if the student asks & $\begin{array}{c}\text { The teacher helps, if the student } \\
\text { asks }\end{array}$ \\
\hline $\begin{array}{c}\text { The teacher gives the pattern } \\
\text { of report to summarising } \\
\text { obtained results. The student } \\
\text { acts on the model }\end{array}$ & $\begin{array}{l}\text { The teacher gives the plan of } \\
\text { report to summarising } \\
\text { obtained results. The student } \\
\text { acts on the plan }\end{array}$ & $\begin{array}{l}\text { The teacher gives the requirements to } \\
\text { report and summarising obtained } \\
\text { results. The student produces the } \\
\text { analysis of obtained results } \\
\text { independently }\end{array}$ & $\begin{array}{l}\text { The student coordinates the form } \\
\text { of report with the teacher and } \\
\text { produces the analysis of obtained } \\
\text { results independently }\end{array}$ \\
\hline
\end{tabular}

\section{Methodology of empirical research}

We have realised the above approach to management of students' educational activity in the practicum of problem solving in informatics for future teachers of computer science. 10 students took part in this work. The information and communication educational environment has been based on the platform of learning management system Moodle. It contains built-in communication resources as well as reference to educational-informative resources and instructivemethodical materials according to programming the basic algorithmic constructions for organization and support of the students' educational activity. The software-instrumental resources (Eclipse environment and the tools of common information technologies) were present at every students' computer. The leading information channel was the interactive lectures, where 
the elements of programs have been analysed in details. The educational activity of the students at this interactive lectures were managed directly, because the students did the notes in the form of parallel development the suggested and analysed algorithms as Java programs. Interactive parts of this lectures involved some students in co-management of educational activity, but some of them were passive and continue execute the tasks in direct management regime, using the ready fragments of code and orientating only at the teacher's commands in the time planning. The students' notes in the form of developed and tested programs became the instructional materials for management students' independent activity in problem solving.

There were created 5 Workshop elements of activity in the course in Moodle environment and suggested 5 series of individual tasks for each student according to the such topics: linear algorithms; branching; cycles; one-dimensional arrays; two-dimensional arrays. Every of this series contained three tasks of different levels. Student should execute one of this task for passing or all tasks for high grade. The first task assumed the direct (but distance) management of students' educational activity, because this task was very similar to the one was analysed at lecture. The second task assumed the direct or co-management. This task was based on some of analysed algorithms but was not fully similar. Students could solve this problem using only the lecture notes (direct management). But sometimes students needed in additional information for solving the problem. They could ask the teacher or colleagues personally or using the built-in tools of Moodle (comanagement) as well as to use some additional information resources (subsidiary management). The third task was difficult and assumed using the algorithmic constructions that were not analysed at lectures. Students had to discuss this problem with the teacher (co-management) or independently use the additional information resources (subsidiary management). So, the students independently and intuitively made the decision on using some of above type of management of their own educational activity for each task according to their educational achievements and skills of independent activity.

Students uploaded the results of the tasks execution to the Workshops. It should be the correct program with the author's tests to prove it correctness. The second phase of students' activity in Workshops was to check and grade the works of the colleagues - assessment phase. Only the students, who have executed the first stage of the task and have submitted their works, could take part in the assessment. The assessment process is creative activity, but its management was direct, because the students assessed according to the simple instruction: +1 point, if the program is submitted and perform the required results; +1 point, if the program correctly work with the author's tests, +1 point, if the reviewer cannot suggest any tests to indicate the bugs. Grading of the assessment phase was produced automatically by comparison of student's given grades with other reviewers' grades for corresponding works. Teacher also took part in the assessment as a reviewer with weight coefficient of 10 .

The teacher carried out pedagogical observation during the course. The students were suggested to design in classroom at fixed time three programs of different levels of difficulty as the final testing in the course. Students, who did not submit their works in time passed the task at additional time in the form of discussion of the results with the teacher personally. Such results were not analysed in this study.

\section{Results and discussion}

Correlation between students' final test results and students' average grades for submitted works has been evaluated to estimate the validity of our assessment tools (Figure 1). Coefficient of Pearson's correlation is 0.70 that is statistical significant at the $5 \%$ significance level.

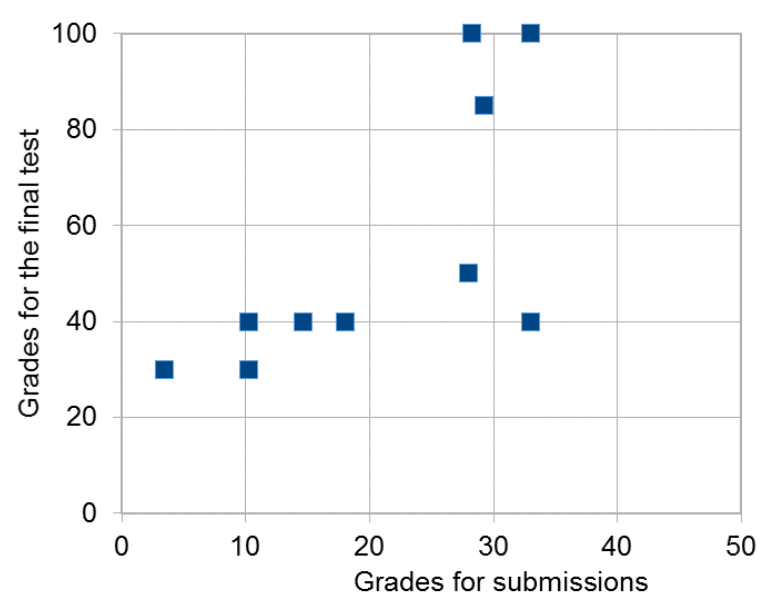

Fig. 1. Correlation between students' final test results and students' average grades for submitted works.

Correlation between the quality of tasks execution by students and their skills in assessment seems to be very good for 7 students (Figure 2), but 3 students with highest results of tasks execution did not take part in assessment, so we cannot prove this correlation statistically, the size of our sample is not enough. According to our pedagogical observation, some students did not take part in the assessment because of their mistakes in time planning.

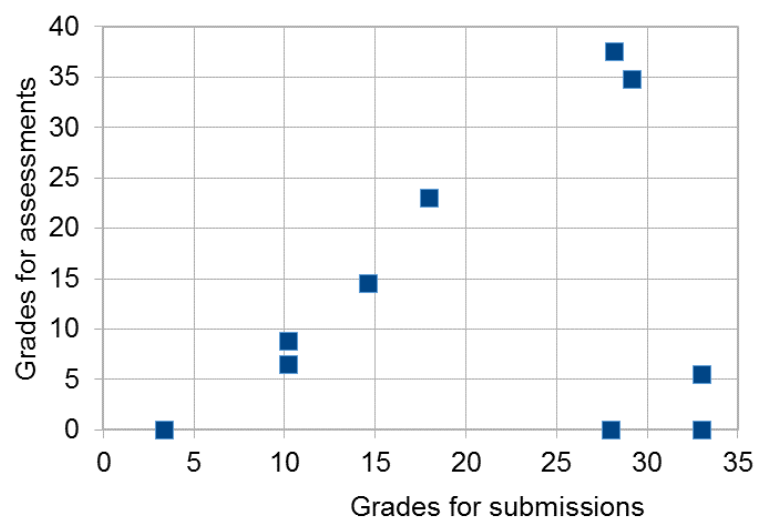

Fig. 2. Correlation between students' average grades for assessment and average grades for submitted works. 
Not all students were able to maintain the proper pace of educational activity progressing from the first topic to the last (Figure 3). Some of them worked effective only in the begin, when direct instructions were full enough to execute some tasks. Because of low motivation and lack of elementary skills in selfmanagement, they did not switch to co-management by their own initiative. These students did not submit some works in time and then passed the tasks at classes with personal participation of the teacher in the process of programming and time planning. So we should develop a mechanism for preventive diagnostic of students' skills in self-management and timely turn them to direct management of educational activity. Also, we see that direct management is an easier way of educational activity for some students. This way seems more comfortable for them. So, we should develop special methods to motivate this category of students for their progressing to self-management of the own educational activity. But other students actively used communication and additional sources to solve problems and did not decrease the level of submissions, when progressing to next, more difficult topic.

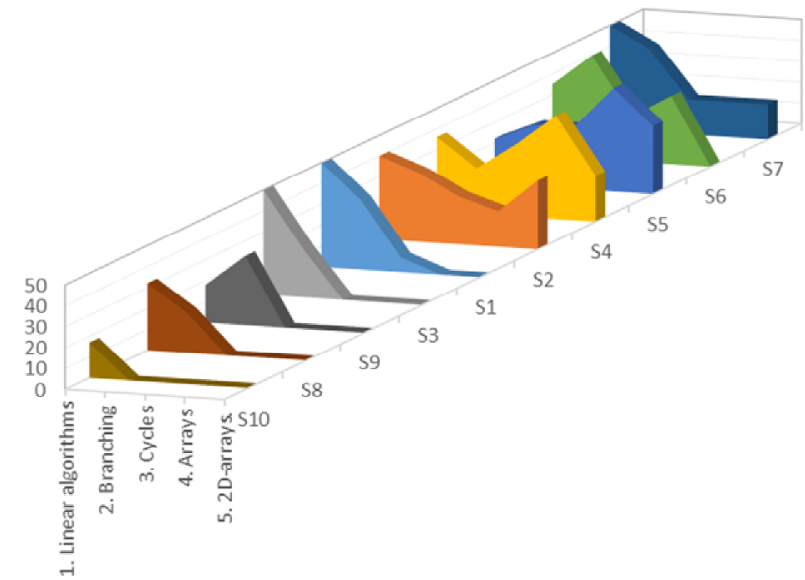

Fig. 3. Students' progressing from the first topic task (1. Linear algorithms) to the last (5. 2D-arrays). Students' names are shown as S1-S10. Vertical axis shows students' grades. The maximum possible grade was 50 .

As expected, the most difficult for the students was the third task in each Workshop, the least difficult - the first task (Figure 4). Analysing the structure of student works according to given criteria (Figure 4), we can conclude that the most problem for students was not the development of the program but provident that it works correctly. The author's tests often were absent or incorrect. The program, if present, often was correct, but sometimes the reviewer's tests could find some bugs.

The analysis of the structure of students' works showed that the students' competency in introspection was not enough. In our opinion, the introspection is one of the leading elements of self-management competency. So the educational tasks should always content some sub-tasks on introspection.

Summarizing the result of our experience in combining of different types of management of students' educational activity, we can conclude that providing the above pedagogical conditions gave us possibility to improve the educational process in "Practicum of problem solving in informatics". Flexible management of students' educational activity with timely turn from the direct management to co-management and subsidiary management with return, when needed, supported the efficiency learning. In despite students' involving in practical labour out of the educational process, the goals of "Practicum of problem solving in informatics" were achieved.

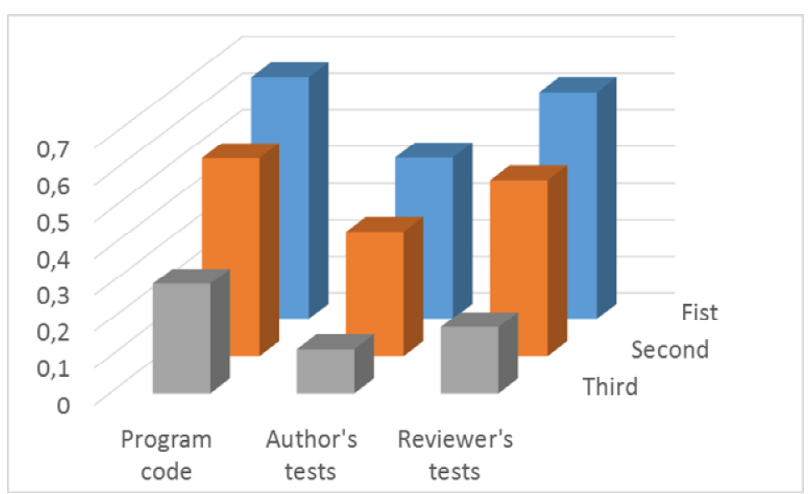

Fig. 4. Part of submissions that satisfy to the criterion (program code, author's test, reviewer's test) on each task (first, second, third). This part was calculated as average for all 5 Workshops.

\section{Conclusions}

Analysis of obtained experimental data in context of our theoretical framework has given the base for such conclusions:

- providing the pedagogical conditions of management of student's educational activity led to improving the educational process in "Practicum of problem solving in informatics";

- flexible management of student's educational activity with timely turn from the direct management to co-management and subsidiary management supported the efficiency learning;

- sometimes the type of management of student's educational activity should be timely turned back to direct management;

- there are two aspects in management of student's educational activity: content of activity choosing and time planning;

- students' competency in introspection is not enough, so the educational tasks should always content some sub-tasks on introspection.

Further work in the field of computer-oriented management of students' independent educational activity we see in developing new methods of students' progress from direct management through comanagement and subsidiary management to selfmanagement in information and communication educational environments, in introduction of these methods into various educational disciplines as well as studying pedagogical and psychological conditions to increase students' motivation for self-management of own educational activity. 


\section{References}

1. O. V. Malykhin, Orhanizatsiia samostiinoi navchalnoi diialnosti studentiv vyshchykh pedahohichnykh navchalnykh zakladiv: teoretykometodolohichnyi aspekt (Management of the independent learning activity of students of pedagogical higher educational institutions: theoretical and methodological aspect). (Publishing house, Kriviy Rig, 2009)

2. A.E. Kiv, V.N. Soloviev, S.O. Semerikov, CTE 2018 - How cloud technologies continues to transform education. CEUR Workshop Proceedings 2433, 1-19 (2019)

3. O. O. Lavrentieva, L. M. Rybalko, O. O. Tsys, A. D. Uchitel, Theoretical and methodical aspects of the organization of students' independent study activities together with the use of ICT and tools. CEUR Workshop Proceedings 2433, 102-125 (2019)

4. S. P. Velychko, S. V. Shulga, ICT tools for support of students' individual work in the study of quantum physics. Information Technologies and Learning Tools $\quad \mathbf{6 5}(3), \quad 103-114 \quad$ (2018). doi:10.33407/itlt.v65i3.2225

5. K. V. Vlasenko, I. V. Sitak, O. O. Chumak, Metodyka kompiuterno-oriientovanoho praktychnoho navchannia dyferentsialnykh rivnian bakalavriv z informatsiinykh tekhnolohii (Methods of computer-oriented practical study of differential equations by bachelors in information technologies). Cherkasy University Bulletin: Pedagogical Sciences 16, 3-14 (2018)

6. S. O. Podlasov, O. V. Matviichuk, V. P. Bryhinets, Elementy zmishanoho navchannia fizyky $\mathrm{V}$ tekhnichnomu universyteti (Elements of blended learning in studying physics in the technical university). Information Technologies and Learning Tools 61(5), 151-161 (2017). doi:10.33407/itlt.v61i5.1741

7. M. A. Kyslova, K. I. Slovak, Method of using mobile learning environments in teaching mathematics of future electromechanical engineer (Metodyka vykorystannia mobilnoho navchalnoho seredovyshcha $\mathrm{u}$ navchanni vyshchoi matematyky maibutnikh inzheneriv-elektromekhanikiv). Information Technologies and Learning Tools 51(1), 77-94 (2016). doi:10.33407/itlt.v51i1.1360

8. O. O. Triakina, O. O. Pavlenko, N. P. Volkova, D. A. Kassim, Usage of E-learning Tools in Selfeducation of Government Officers Involved in Global Trade Activities. CEUR Workshop Proceedings 2257, 173-181 (2018)

9. H. M. Kravtsov, Methods and Technologies for the Quality Monitoring of Electronic Educational Resources. CEUR Workshop Proceedings 1356, 311-325 (2015)

10. L. Bilousova, O. Kolgatin, L. Kolgatina, Computer Simulation as a Method of Learning Research in
Computational Mathematics. CEUR Workshop Proceedings 2393, 880-894 (2019)

11. B. I. Kruk, O. B. Zhuravleva, Analyz transformatsyi $\mathrm{v}$ ynnovatsyonnom pedahohycheskom obrazovanyy (Analysis of transformations in innovative pedagogical education). Paper presented at III AllRussian scientific and practical Internet-conference "Innovative directions in pedagogical education" (2010), http://econf.rae.ru/article/5138. Accessed 30 Dec 2019

12. M. Markov, Teoriia sotsialnogo upravleniia (The theory of social management). (Progress, Moskva, 1976)

13. I. B. Itelson, Matematicheskie $i$ kiberneticheskie metody v pedagogike (Mathematical and cybernetic methods in pedagogy). (Prosveshchenie, Moskva, 1964)

14. Yu. M. Korshunov, Matematicheskie osnovy kibernetiki (Mathematical foundations of cybernetics). (Energoatomizdat, Moskva, 1987)

15. A. V. Filippov, Voprosy psikhologii upravleniia (Issues of Management Psychology). Psychological Journal 1(2), 17-23 (1980)

16. V. Ya. Nechaev, Sotsiologiia obrazovaniia (Sociology of Education). (Izdatelstvo Moskovskogo universiteta, Moskva, 1992)

17. V. A. Yakunin, Obuchenie kak protsess upravleniia: Psikhologicheskie aspekty (Learning as a management process: Psychological aspects). (Izdatelstvo Leningradskogo universiteta, Leningrad, 1988)

18. Novyi tlumachnyi slovnyk ukrainskoi movy (New Interpretative Dictionary of the Ukrainian Language), vol. 4 (Akonit, Kyiv, 1999) 